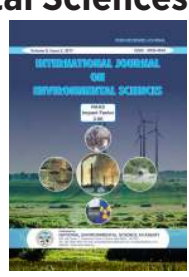

\title{
MAPPING AND MONITORING OF WETLAND ECOSYSTEMS: A CASE STUDY ON HARIKE AND KESHOPUR WETLAND OVER PUNJAB REGION, INDIA
}

\author{
Mohit Arora $^{{ }^{*} \text {, Sashikant Sahoo }}{ }^{1}$, Sarishty Sharma ${ }^{2}$, Syed Shabih Hassan ${ }^{3}$ and Brijendra Pateria ${ }^{1}$ \\ ${ }^{1}$ Punjab Remote Sensing Centre, PAU Campus, Ludhiana, India \\ ${ }^{2}$ Department of Geoinformatics, Panjab University, Chandigarh, India \\ ${ }^{3}$ Department of Fisheries Resource Management, College of Fisheries, \\ Guru Angad Dev Veterinary and Animal Sciences University, Ludhiana, India
}

\section{Research Article}

Received: 20.05.2020

Accepted: 05.06.2020

Published: 12.06.2020

\begin{abstract}
Wetland plays a vital role in sustainable ecological development. They hold balanced environment conditions and filter the surface and sub-surface water and moderate the local weather condition. But now-a-days wetlands are shrinking quickly all over world due to climate change \& anthropogenic activities and extinction of wetlands agitates the local environmental conditions with contexts to water and soil conditions. This study is mainly focused on climate change impacts on wetland ecosystems over Harike and Keshopur wetland in Punjab region, India. Harike wetland is one of largest wetland in northern part of India, which is designated as Ramsar site. The Landsat imageries and climate parameters (includes land surface temperature and rainfall) have been used to extract spatial and temporal information over wetlands during period from 2009 to 2020. Landsat data have been analysed in two phases: Pre-monsoon and Post-Monsoon. Wetland area has been classified into five different classes: agriculture, water, built-up, aquatic vegetation1, and aquatic vegetation2. These analyses showed that wetland area has been reduced over a period of ten years and much area has been converted in agricultural land and built-up. The intense anthropogenic activities have resulted more changes in the wetland over both regions. The present study specifies that wetland ecosystem monitoring is essential for policy makers for sustainable management and also concluded that the significant reduction of highly biodiversity wetland area is required to conserve.
\end{abstract}

Keywords: Landsat Images, Ramsar Convention, Wetland Conservation, Land Surface Temperature (LST), Rainfall.

\section{INTRODUCTION}

Wetlands are among the complex, most productive and sensitive ecosystems. Wetlands encompass a large and heterogeneous spectrum of aquatic habitats and are found at the interface between terrestrial ecosystems (such as forests and grasslands) and waters (such as rivers, lakes, estuaries and oceans), strongly dependent on the water cycle. Wetlands plays an important role in the ecological system which cover 6\% of the Earth's surface ( 1280 million ha) and contain about $12 \%$ of the global carbon pool, (IPCC 1996; Sahagian and Melack 1998; Finlayson and Davidson, 1999; Ferrati et al. 2005; Junk et al., 2013; Barros and Albernaz, 2014; Singh et al., 2020). Wetlands are a major feature of the landscape in almost all parts of the earth (Singh et al., 2020) and act as critical habitats for a variety of plants, fish,

*Corresponding author: mohitarora.prsc@gmail.com 
shellfish, and other wildlife (Klemas, 2011). Wetlands in India are distributed in different geographical regions and area coverage is about 58.2 million hectare (ha) which accounting for nearly $4.7 \%$ of the total geographical area and is important repositories of aquatic biodiversity (Singh et al., 2020). These wetland ecosystems convey resilience to our communities, provide a wide range of ecosystem services such as food (e.g. fisheries), maintenance of biodiversity, drinking water supply (e.g. often recharged through wetlands), water quality improvement through filtering of agricultural and industrial waste, carbon cycling and climate regulation, service to human population and welfare (e.g. water purification, climate regulation, flood regulation, coastal protection, recreational opportunities, tourism, etc.). During periods of flooding, they trap suspended solids and nutrient loads. The overall high specific richness, endemism levels and productivity, many wetlands have a world conservation status. The Ramsar Convention is one of the global intergovernmental treaties which addresses the conservation and wise use of wetlands (Erwin, 2009). In 1975 Ramsar Convention has been introduced to conserve the wetland resources on a global scale. The Ramsar Convention on wetlands has long recognised the need to develop techniques that can fill gaps in baseline inventory. According to the Ramsar Convention on Wetlands, wetlands include all inland aquatic habitats (permanent or temporary, whether fresh, brackish, or saline, and including lakes, streams, rivers and inland seas), coastal systems shallower than $6 \mathrm{~m}$ depth at low tide (lagoons, estuaries, marshes, mangroves, seagrass beds, mud flats and coral reefs), and human-made systems such as reservoirs $\left(6,000-7,000 \mathrm{~km}^{3}\right.$ according to recent estimates) (Lucas and Lloréns, 2008). These Ramsar wetlands are important for supporting the great diversity of ecosystem, hydrology, environment, mammalian species, are creational spot for the nature lovers, migratory bird watchers, researchers, etc.
Despite their vital function, many wetlands are under threat and being destroyed worldwide due to climate change and anthropogenic activities (Sivakumar and Ghosh, 2016; Kundapura et al., 2019; Singh et al., 2020). Climate change refers to any change in climate condition for any period of time. It may present great challenge to conserve wetlands and will make future efforts to restore and manage wetlands more complex (Erwin, 2009). It causes for shift in species composition, habitat destruction and degradation in existing wetlands worldwide (Hulme, 2005; Erwin, 2009). The major consequences of climate change are increased temperatures (means heat stress in wildlife)/humidity, changes in precipitation and evapotranspiration patterns, changes in quantity and quality of their water supply, increased flooding, landslide, land-use changes, increased soil erosion and emissions of greenhouses gases (Ferrati et al. 2005; IPCC 2007a) which directly or indirectly affect the ecological processes, biological resources and life sustaining system of the nature. Over the past three decades, many researchers are looking at the ecological and hydrological impacts resulting from climate changes over the world (Erwin, 2009). Tropical wetlands are considered highly vulnerable to climate change and degradation seems to progress faster than other ecosystems. The climate change impacts on wetland ecosystems not only the loss of biodiversity but also sources of economic benefits. Anthropogenic impacts have also been more noteworthy than natural impacts. Anthropogenic activities includepopulation's growth, urbanization, agricultural expansion, infrastructure development, etc. Climate change together with human pressure has changed ecosystems more rapidly and extensively in last five decades (Kumar and Chopra, 2009). Many wetlands are disappeared and converted to industrial, agricultural and residential use.

The wetlands over Punjab state (India) are not stable and climate changes are deteriorating. The National Wetland Atlas (2011) mapped 1381 wetlands in Punjab state which covered 86,283 ha which accounted for $1.71 \%$ of the total geographical area of the region (SAC, 2011). 
There are about 40 (8 natural and 32 man-made) significant wetlands lies in the Punjab state (Singh et al., 2020). The wetlands management requires an understanding of the scientific aspects of wetlands, prevention or reduction of additional stress, balanced with legal, institutional and economic realities that can reduce the ability of wetlands changes. The wetlands are facing various challenges in the form of inherent problems both natural and manmade and many wetlands are under threat from developmental activities and population pressure. The decreasing water flow in perennial rivers, less rainfall in monsoon season, increasing temperature, etc. are main climate change factors which are responsible for wetland degradation over Punjab region. Wetlands are highly dependent on water levels. The main wetlands in Punjab region which includes in Ramsar site are Harike wetland (notified in 1990), Ropar wetland (2002), Kanjli wetland (2002), Keshopur-Miani community reserve, Beas conservation reserve and Nangal wildlife sanctuary. Thisstudy is mainly focused on monitoring of wetland ecosystems over Harike and Keshopur wetland in Punjab region and how Land surface temperature has impacted on the wetland ecosystems.

\section{STUDYAREA}

Punjab is situated in the north state of India. The Punjab state extends from the latitudes $29.30^{\circ} \mathrm{N}$ to $32.32^{\circ} \mathrm{N}$ and longitudes $73.55^{\circ} \mathrm{E}$ to $76.50^{\circ} \mathrm{E}$. Punjab state is divided into 22 districts and is bounded by Jammu and Kashmir in the north, Himachal Pradesh in north-east and east, Haryana in south-east and south, Rajasthan in south and south-west and shares the international boundary with Pakistan on western side (Figure 1). The three perennial rivers namely: Beas, Satluj and Ravi along with their tributaries drain the state. The longest river of Punjab: the Satluj River is a major source of water supply for irrigation, drinking, washing, bathing, etc. which originates from Manasarover Lake in Tibet and enters
Punjab near Nangal, moves on to plains at Ropar, passes through districts SBS Nagar, Ludhiana, Jalandhar, Kapurthala, Moga, Firozpur and reaches at Harike wetland (Ramsar site) before crossing over to Pakistan (Sharma et al., 2018). Punjab is an important food grain producing state of India and the role of wetland as sources of irrigation, hydropower generation and as shelters for varieties of birds cannot be ignored. Due to their immense role in biodiversity protection, three wetlands (Harike, Roper, and Kanjli) are included in the Ramsar list and many more are declared wetlands of national importance. This study is mainly concerned about the 2 major sites Harikewetland (area coverage $222 \mathrm{~km}^{2}$ ) which is situated in Tarantaran district and Keshopur wetland (area coverage $7.1 \mathrm{~km}^{2}$ ) which is situated in Gurdaspur district.

Harike wet land also known as "Hari-ke-Pattan" with Harike lake it is an largest wetland in northern India. It is located between latitudes of $31^{\circ} 05^{\prime} 15^{\prime \prime}$ to $31^{\circ} 40^{\prime} 15^{\prime \prime} \mathrm{N}$ and longitudes $74^{\circ} 55^{\prime}$ $30^{\prime \prime}$ to $75^{\circ} 07^{\prime} 30^{\prime \prime} \mathrm{E}$ and lies at a distance of $57 \mathrm{~km}$ from the historic city of Amritsar and about 150 $\mathrm{km}$ from the Punjab state capital Chandigarh. The head works is located in downstream of confluence of the Beas and Sutlej River just south of Harike village. The rich biodiversity of the wetland which plays a vital role in maintaining the hydrological balance in the catchment with its vast variety fauna of waterfowls including a number of globally threatened species has been responsible for the recognition accorded to this wetland in 1990, by the Ramsar Convention, as one of the Ramsar sites in India, for conservation, development and preservation of the ecosystem. Keshopur wetland is also known as Keshopur-Miani community reserve or chhmab in local Punjabi dialect. It is located between latitude of $32^{\circ} 04^{\prime} 23^{\prime \prime}$ to $32^{\circ} 06^{\prime} 33^{\prime \prime} \mathrm{N}$ and longitude of $75^{\circ} 21^{\prime} 6^{\prime \prime}$ to $75^{\circ} 24^{\prime} 26^{\prime \prime} \mathrm{E}$ lies at a distance of $\sim 5 \mathrm{~km}$ from the city of Gurdaspur. Keshopur community reserve is a dynamic freshwater ecosystem. It is the first ever notified community reserve of India under the wildlife 


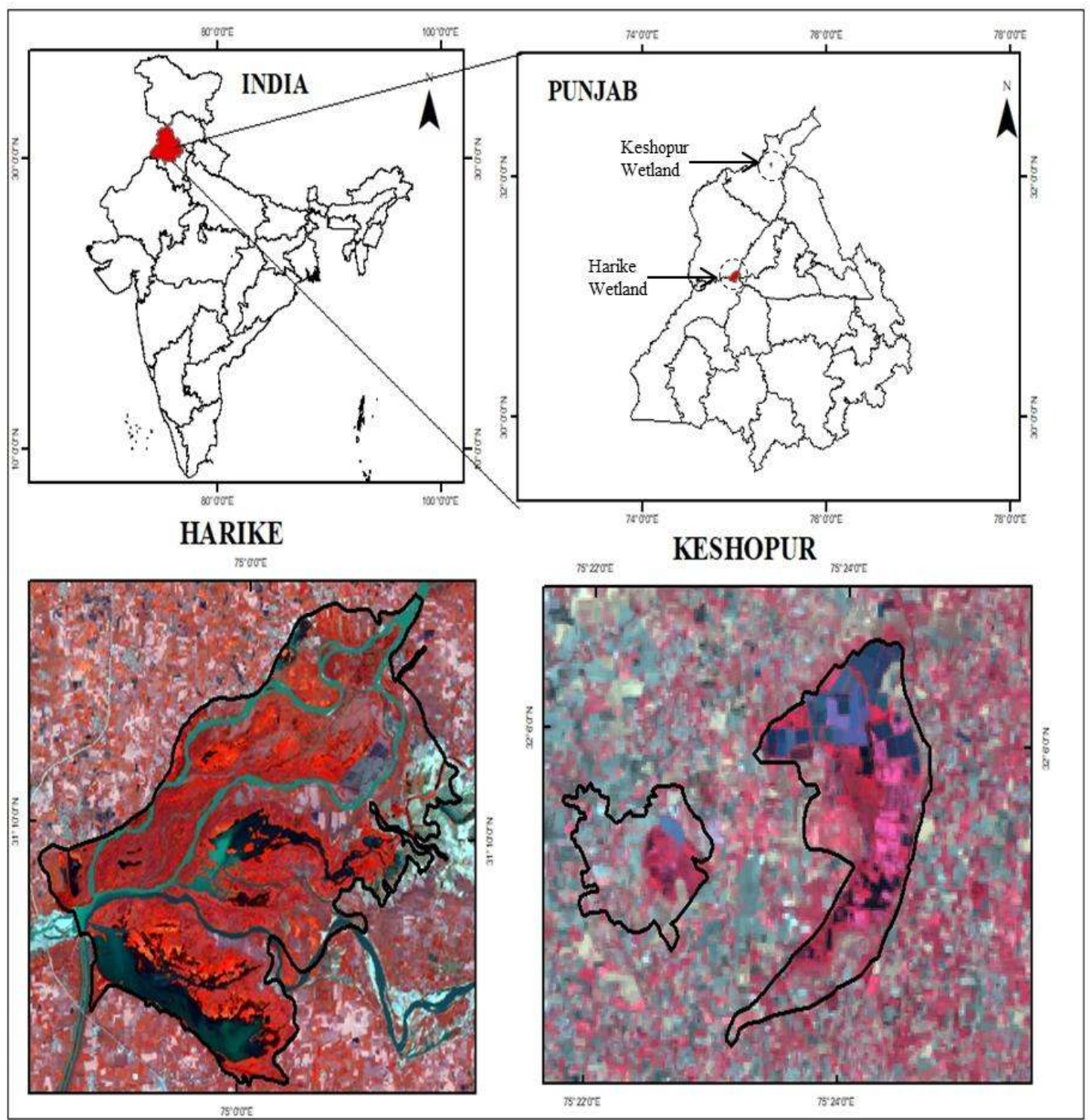

Figure 1: Location of two wetland sites (Harike and Keshopur) over Punjab region.

protection act, 1972 (amended 2002). It is witnessed 4,500 birds but 2016 it was around 25000 birds.

\section{MATERIALS AND METHODOLOGY}

This study used Landsat-5 \& 8 (30 m resolution) for spatial pattern of LST and wetland extent mapping and monitoring during period from 2009 to 2020 for both season (Pre- and Post-monsoon) (Table-1) over Harike and Keshopur wetland in
Punjab region. Landsat-5 \& 8 data has been taken from USGS site (Figure 2).The temporal resolution of Landsat data is 16 days. Landsat-5 data contains 7 bands whereas the Landsat-8 contains 11 bands (Table 1). The Landsat 5 \&8 level-2 imagery has been used for decadal change analysis of wetland extent and level-0 imagery has been used for computing spatial extent of LST.NDVI based emissivity has been taken to derive spatial pattern of LST from Landsat-5 \& 8 
imagery. The all collected data have been pre- and post-processed through ERDAS Imagine, ENVI
Classic software and ARC GIS used for mapping and statistical analysis.

Table 1:Landsat satellite data information's during both seasons (Pre- and Post-monsoon).

\begin{tabular}{|l|c|c|c|c|}
\hline SEASONS & SATELLITE & $\begin{array}{c}\text { DATE OF } \\
\text { ACQUIRED } \\
\text { DATA }\end{array}$ & Path/Row & $\begin{array}{c}\text { Cloud Cover } \\
\text { (\%) }\end{array}$ \\
\hline \multirow{3}{*}{ Pre-Monsoon } & Landsat 5 & 13 March 2009 & $148 / 38$ & $<10$ \\
\cline { 2 - 5 } & Landsat 5 & 10 February 2015 & $148 / 38$ & $<10$ \\
\cline { 2 - 5 } & Landsat 8 & 10 February 2020 & $148 / 38$ & $<10$ \\
\hline Post-Monsoon & Landsat 5 & 07 October 2009 & $148 / 38$ & $<10$ \\
\cline { 2 - 5 } & Landsat 5 & 21 October 2014 & $148 / 38$ & $<10$ \\
\cline { 2 - 5 } & Landsat 8 & 19 October 2019 & $148 / 38$ & $<10$ \\
\hline
\end{tabular}

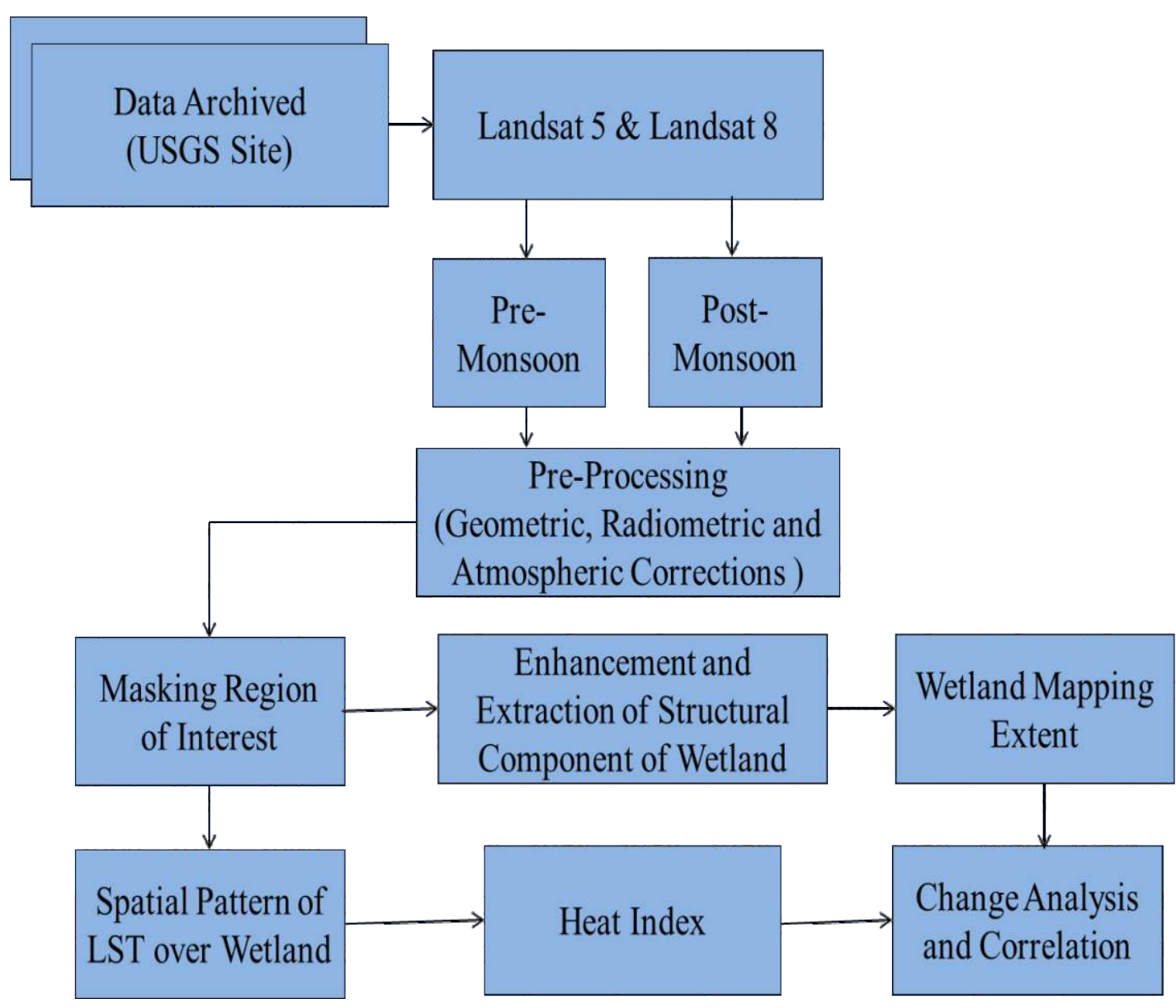

Figure 2: Overview of satellite data analysis procedure. 
Table 2: Spectral bands and wavelength ranges of Landsat-5 and 8 and their uses.

\begin{tabular}{|l|l|c|c|c|}
\hline Sr. No. & Satellite Data & Spectral Bands & Use Area & Wavelength Range (nm) \\
\hline 1. & Landsat-8 & Band 1 & Aerosol/Costal & $0.45-0.52 / 0.433-0.453$ \\
\hline 2. & Landsat-5 \& 8 & Band 2 & Blue & $0.450-0.515$ \\
\hline 3. & Landsat-5 \& 8 & Band 3 & Green & $0.525-0.600$ \\
\hline 4. & Landsat-5 \& 8 & Band 4 & Red & $0.630-0.680$ \\
\hline 5. & Landsat-5 \& 8 & Band 5 & NIR & $0.76-0.90 / 0.845-0.885$ \\
\hline 6. & Landsat-5 \& 8 & Band 6 & SWIR & $1.55-1.75 / 1.560-1.660$ \\
\hline 7. & Landsat-5 \& 8 & Band 7 & SWIR2 & $2.80-2.35 / 2.100-2.300$ \\
\hline 8. & Landsat-8 & Band 8 & Panchromatic & $0.500-0.680$ \\
\hline 9. & Landsat-8 & Band 9 & Cirrus & $1.360-1.390$ \\
\hline 10. & Landsat-5 \& 8 & Band 10 & Thermal 1 & $10.31-12.36 / 10.6-11.2$ \\
\hline 11. & Landsat-8 & Band 11 & Thermal 2 & $11.5-12.5$ \\
\hline
\end{tabular}

\section{Estimating LST}

For the retrieval of emissivity-corrected LST maps, following steps are followed: First, the DNs of thermal bands were converted to spectral radiance by the following expression (Chen et al. 2006; Pan 2015):

$\mathrm{L}_{\lambda}=\left[\left(\mathrm{L}_{\max }-\mathrm{L}_{\min }\right) /\left(\mathrm{QCAL}_{\max }-\mathrm{QCAL}_{\min }\right)\right]^{*}$

$\left(\mathrm{QCAL}-\mathrm{QCAL}_{\min }\right)+\mathrm{L}_{\min }$

where $L_{\lambda}$ is the spectral radiance and $\lambda$ is the wavelength, $\mathrm{QCAL}_{\min }$ and $\mathrm{QCAL}_{\max }$ are the minimum and maximum $\mathrm{DN}$ of the images respectively, QCAL $=\mathrm{DN}$, and $\mathrm{L}_{\max }$ and $\mathrm{L}_{\min }$ are the spectral radiances for the thermal band at $\mathrm{QCAL}_{\text {min }}$ and $\mathrm{QCAL}_{\max }$, respectively (given in the header file of the images).

Then, the brightness temperature of the field of view of satellite under the assumption of uniform emissivity is estimated from the spectral radiance $\left(\mathrm{L}_{\lambda}\right)$ using the following expression (Weng, Lub, and Schubringa 2004; Chen et al. 2006; Yue et al. 2007; Pan 2015): Brightness temperature, TB (K):

$\mathrm{TB}=\mathrm{K}_{2} / \ln \left[\left(\mathrm{K}_{1} / \mathrm{L}_{\lambda}\right)+1\right]$ where $\mathrm{K}_{1}(\mathrm{~K})$ and $\mathrm{K}_{2}(\mathrm{Wm}-2)$ are pre-launch calibration constants for Landsat 7 and 8 sensors. Finally, the LST $(\mathrm{K})$ can be derived from the brightness temperature $(\mathrm{K})$ by the following formula (Weng, Lub, and Schubringa 2004; Yue et al. 2007):

LST $\left({ }^{\circ} \mathrm{C}\right)=\mathrm{TB} /[1+\mathrm{W}(\mathrm{TB} / \mathrm{p}) * \ln (\varepsilon)]-273.15$

where, $w$ is the wavelength of emitted radiance; $\mathrm{p}$ $=\mathrm{h} \times \mathrm{c} / \sigma=1.438 \times 10-2 \mathrm{mK}(\sigma$ is the Boltzmann constant, $\mathrm{h}$ is the Planck constant, and c is the velocity of light).

$\varepsilon=0.004 * \mathrm{Pv}+0.986$

$\mathrm{PV}=\left[\left(\mathrm{NDVI}-\mathrm{NDVI}_{\min }\right) /\left(\mathrm{NDVI}_{\max }-\mathrm{NDVI}_{\min }\right)\right]^{2}$

where, $\mathrm{Pv}$ is the fractional vegetation or proportion of vegetation.

\section{RESULTSAND DISCUSSION}

Spatial and Temporal variations of wetlands during Pre- and Post-Monsoon:

This study shows that Harike and Keshopurwet land has experienced significant changes due to 
influences of natural and human activities inside the sanctuary area during period from 2009 to 2020. Landsat data sets has been taken from the interval of 5 years. This study used Land- $5 \& 8$ data for mapping and monitoring wetland extent both spatially and temporally (Figure 3 \& 4). Monitoring wetland changes spatially and temporally are not feasible by ground measurements due to the high cost and limited observations. We classified Landsat images in five different classes includes agriculture, water, build-up, aquatic vegetation-1 and aquatic vegetation-2. This study used aquatic vegetation1 for algal bloom and aquatic vegetation- 2 for vegetation above water.

\section{Dynamics in Harike wetlands during Pre- and Post-Monsoon:}

Harike wetlands have experienced significant changes due to influences of natural and human activities inside the sanctuary area during Preand Post-monsoon period from 2009 to 2020. Figure 3 illustrates the land use/land cover of Harike wetland ecosystem. In the year 2009 Premonsoon season, Harike wetland comprised 2276.10 ha of agriculture, 1526.23 ha of water, 8.12 ha of built-up, 641.10 ha of aquatic vegetation-1 and 2926.79 ha of aquatic vegetation-2 whereas in the year 2020 Premonsoon season, it comprised 1591.00 ha of agriculture, 2018.53 ha of water, 19.32 ha of builtup, 480.24 ha of aquatic vegetation-1 and 3236.75 ha of aquatic vegetation-2. After analysis of these datasets we found that the net increase has been seen in water, built-up and aquatic vegetation-2 categories and net decrease has been seen in agriculture andaquatic vegetation-1 categories (Table 3). Similarly in the year 2009 Post monsoon season, the study area comprised 1212.10 ha of agriculture, 1670.62 ha of water, 8.16 ha of built-up, 621.78 ha of aquatic vegetation-1 and 3777.81 ha of aquatic vegetation-2 whereas in the year 2019 Postmonsoon season, it comprised 1554.65 ha of agriculture, 1878.34 ha of water, 11.41 ha of builtup, 479.73 ha of aquatic vegetation- 1 and 3338.66 ha of aquatic vegetation-2. Analysis of these datasets found that the net increase has been seen in agriculture, water and built-up categories and net decrease has been seen in aquatic vegetation-1 andaquatic vegetation- 2 categories (Table 3 ). The entire Harike wetland is very fertile and expansion of cultivated land can be seen in the northern part and along river Sutlej in the southern part. Encroachment inside sanctuary area for cultivation and grazing activities are considered major obstacles in management of the wetland.

\section{Dynamics in Keshopur wet lands during Pre- and Post-Monsoon:}

Keshopur wet lands have also experienced significant changes due to influences of natural and human activities inside the sanctuary area during Pre- and Post-monsoon period from 2009 to 2020. Figure 3 illustrates the land use/land cover of Keshopur wetland ecosystem. In the year 2009 Pre-monsoon season, Keshopur wetland comprised 301.05 ha of agriculture, 148.02 ha of water, 1.90 ha of built-up, 110.12 ha of aquatic vegetation- 1 and 60.56 ha of aquatic vegetation-2 whereas in the year 2020 Pre-monsoon season, it comprised 230.79 ha of agriculture, 273.04 ha of water, 7.10 ha of built-up, 53.83 ha of aquatic vegetation-1 and 77.30 ha of aquatic vegetation2. After analysis of these datasets we found that the net increase has been seen in water, built-up and aquatic vegetation-2 categories and net decrease has been seen in agriculture and aquatic vegetation-1 categories (Table 4). Similarly in the year 2009 Post monsoon season, the study area comprised 353.90 ha of agriculture, 136.14 ha of water, 1.90 ha of built-up, 88.65 ha of aquatic vegetation-1 and 17.90 ha of aquatic vegetation-2 whereas in the year 2019 Post-monsoon season, it comprised 340.64 ha of agriculture, 106.50 ha of water, 5.45 ha of built-up, 84.83 ha of aquatic vegetation-1 and 54.15 ha of aquatic vegetation2. Analysis of these datasets found that the net increase has been seen in built-up and aquatic vegetation-2 categories and net decrease has been seen in agriculture, water andaquatic vegetation-1 categories (Table 4). 


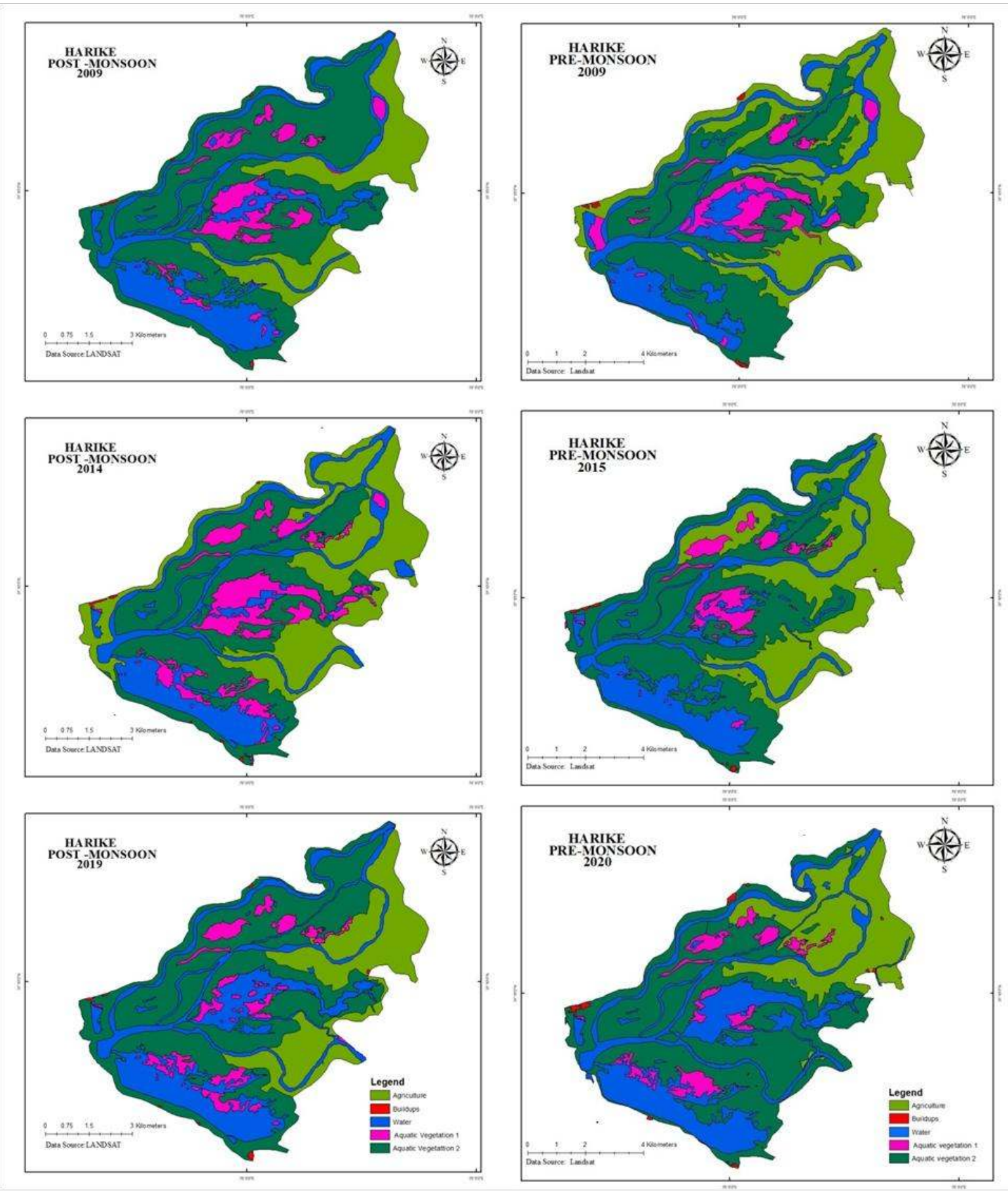

Figure 3: Classified image of Harike wetland during Pre- and Post-monsoon season

This study shows that the dominant category over Harike and Keshopur wetland is seen as Aquatic vegetation and agriculture whereas built-up are comparatively less according to area coverage but the increase effect has been seen in recent years. Analysis of these datasets found that the net 
Table 3: Total area coverage of different class inside Harike wetland for both season (Pre- and Post-monsoon) during period 2009 to 2020 in hectares.

\begin{tabular}{|l|l|c|c|c|c|c|c|c|c|}
\hline & & \multicolumn{4}{|c|}{ Post - Monsoon } & \multicolumn{4}{c|}{ Pre- Monsoon } \\
\hline $\begin{array}{l}\text { Sr. } \\
\text { No. }\end{array}$ & Category name & $\mathbf{2 0 0 9}$ & $\mathbf{2 0 1 4}$ & $\mathbf{2 0 1 9}$ & $\begin{array}{c}\text { Net } \\
\text { Changes }\end{array}$ & $\mathbf{2 0 0 9}$ & $\mathbf{2 0 1 5}$ & $\mathbf{2 0 2 0}$ & $\begin{array}{c}\text { Net } \\
\text { Changes }\end{array}$ \\
\hline 1. & Agriculture & 1212.10 & 2263.831 & 1554.65 & 342.55 & 2276.10 & 2214.94 & 1591.00 & -623.9 \\
\hline 2. & Water & 1670.62 & 1445.88 & 1878.34 & 207.72 & 1526.23 & 1622.30 & 2018.53 & 557.27 \\
\hline 3. & Built-up & 8.164 & 10.4 & 11.41 & 3.246 & 8.12 & 10.52 & 19.32 & 11.2 \\
\hline 4. & Aquatic Vegetation 1 & 621.782 & 885.46 & 479.73 & -142.052 & 641.10 & 379.46 & 480.24 & -160.76 \\
\hline 5. & Aquatic vegetation 2 & 3777.81 & 2626.85 & 3338.66 & -439.15 & 2926.79 & 3440.61 & 3236.75 & 310 \\
\hline
\end{tabular}

increase during pre-monsoon has been seen in water, built-up and aquatic vegetation-2 categories and net decrease has been seen in aquatic vegetation-1 and agriculture categories. Similarly for post-monsoon season the net increase has been seen in agriculture, water and built-up. The overall decadal change has been seen where it has been observed in water with 136.04 ha increase, buildups with 5.2 ha increase and Aquatic vegetation 2 with 16.74 ha increase. The built-up has been increased due to development of town concentrations and water area has been increased due to the adverse effect of rainfall. The agriculture area has been decreased because of social atmosphere, problems of soil, overgrazing, land surface temperature variations. The loss of agricultural land is due largely to land degradation, such as erosion, which is when soil components move from one location to another by wind or water. Agricultural land is also being lost because it is being converted in barren land and for other purposes, such as highways, housing and factories. This study also used land surface temperature data to see the spatial and temporal variations over both wetland ecosystems.

Table 4: Total area coverage of different class inside Keshopur wetland for both season (Pre- and Post-monsoon) during period 2009 to 2020 in hectares.

\begin{tabular}{|l|l|c|c|c|c|c|c|c|c|}
\hline & & \multicolumn{4}{|c|}{ Post - Monsoon } & \multicolumn{4}{c|}{ Pre- Monsoon } \\
\hline $\begin{array}{l}\text { Sr. } \\
\text { No. }\end{array}$ & Category name & 2009 & $\mathbf{2 0 1 4}$ & $\mathbf{2 0 1 9}$ & $\begin{array}{c}\text { Net } \\
\text { Changes }\end{array}$ & $\mathbf{2 0 0 9}$ & $\mathbf{2 0 1 5}$ & $\mathbf{2 0 2 0}$ & $\begin{array}{c}\text { Net } \\
\text { Changes }\end{array}$ \\
\hline 1. & Agriculture & 1212.10 & 2263.831 & 1554.65 & 342.55 & 2276.10 & 2214.94 & 1591.00 & -623.9 \\
\hline 1. & Agriculture & 353.9 & 338.5 & 340.64 & -12.36 & 301.05 & 261.40 & 230.79 & -70.26 \\
\hline 2. & Water & 136.14 & 110.8 & 106.5 & -29.64 & 148.023 & 235.68 & 273.04 & 136.04 \\
\hline 3. & Built-up & 1.90 & 3.47 & 5.45 & 3.55 & 1.90 & 4.14 & 7.1 & 5.2 \\
\hline 4. & Aquatic vegetation 1 & 88.65 & 92.43 & 84.83 & -3.82 & 110.12 & 36.0 & 53.83 & -56.29 \\
5. & Aquatic vegetation 2 & 17.90 & 51.31 & 54.15 & 36.25 & 60.56 & 87.20 & 77.30 & 16.74 \\
\hline
\end{tabular}

Assessment of Land Surface Temperature (LST) and Heat Index over Harike and Keshopur Wetland Ecosystems:

The spatial pattern of heat index (HI) for both seasons (Pre- and Post-monsoon) have been derived from Landsat-5 and 8 data for the spatial and temporal variations over both wetlands (Figure 5\&7). The result shows that HI pattern 


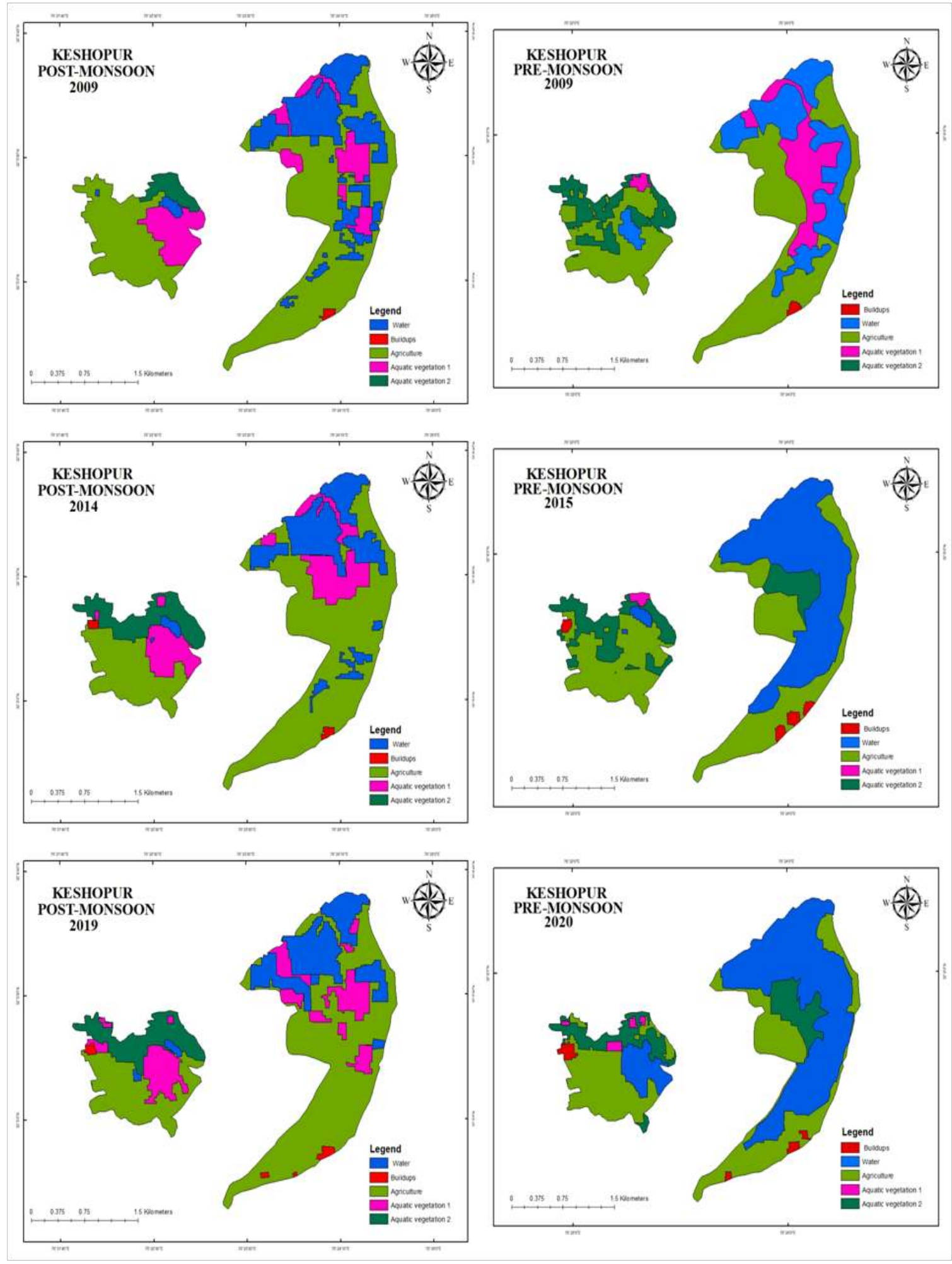

Figure 4: Classified image of Keshopur wetland during Pre- and Post-monsoon season. 
over the study region varies considerably. HI from LST data is calculated using the following equation (Mathew et al., 2016):

$\mathrm{HI}_{\text {index }}=\left(\mathrm{LST}_{\mathrm{i}}-\mathrm{LST}_{\text {min }}\right) /\left(\mathrm{LST}_{\text {max }}-\mathrm{LST}_{\text {min }}\right)$

Where, $\mathrm{LST}_{\mathrm{i}}$ is the value of a particular pixel in an
LST distribution image, $\mathrm{LST}_{\max }$ and $\mathrm{LST}_{\text {min }}$ are the maximum and minimum values of the temperature range of LST distribution image. Harike wetland has experienced high land surface temperature as compared with Keshopur wetland during period from 2009 to 2020.
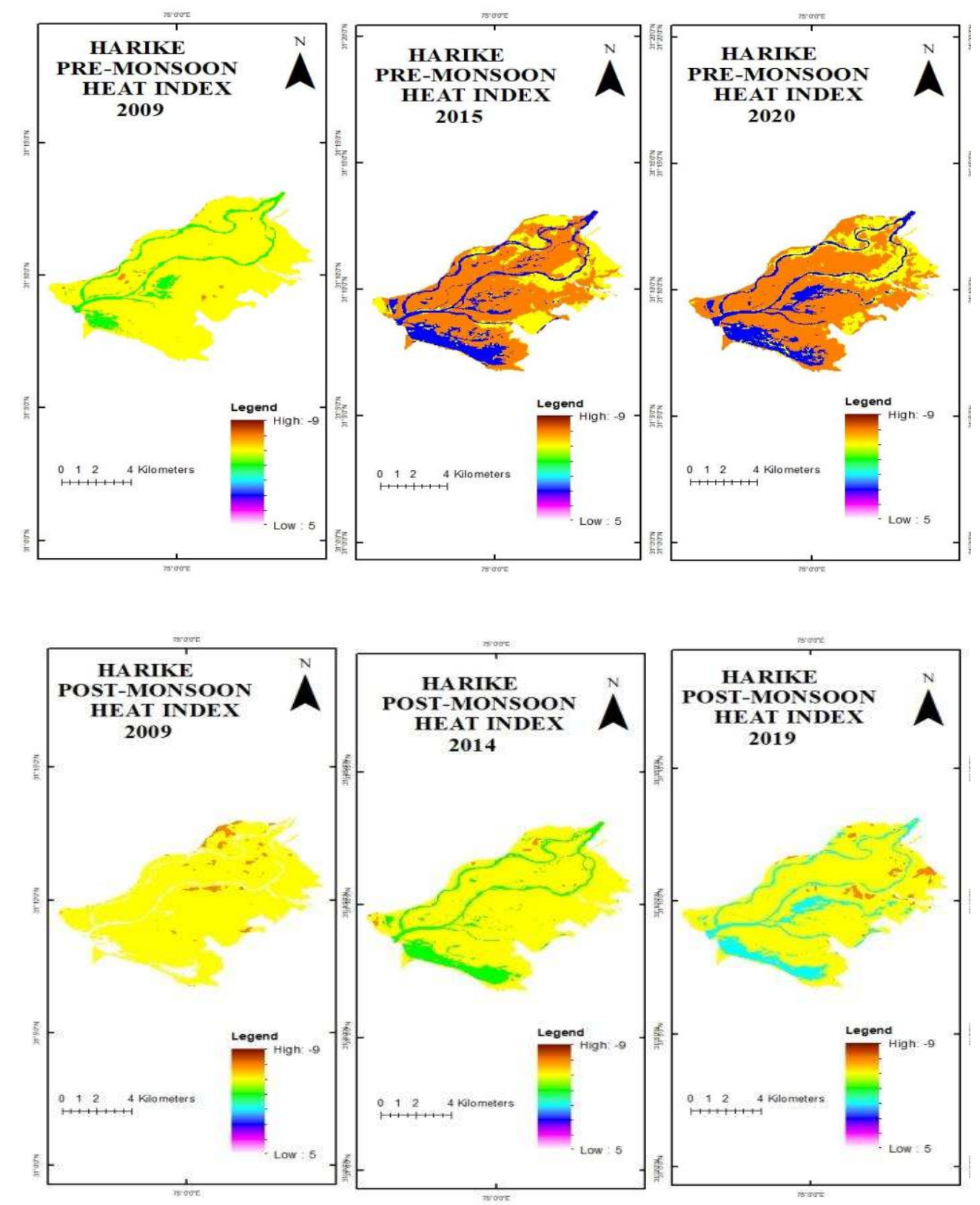

Figure 5:Variations of heat index derived from LST value over Harike wetlands during Pre- and Post-Monsoon period. 


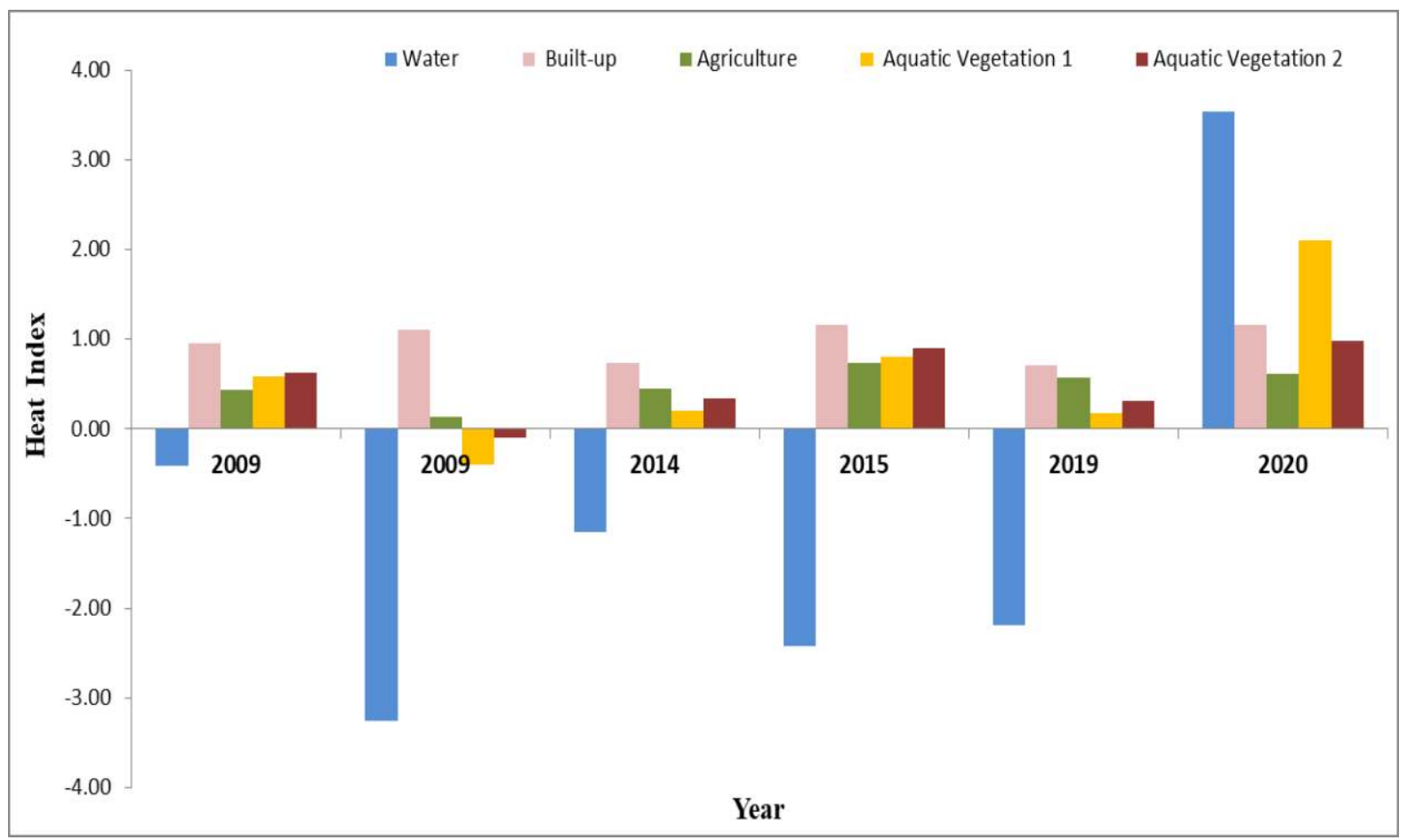

Figure 6: Shows the graphical representation of effect of heat index on each wetland class over Harike wetland.

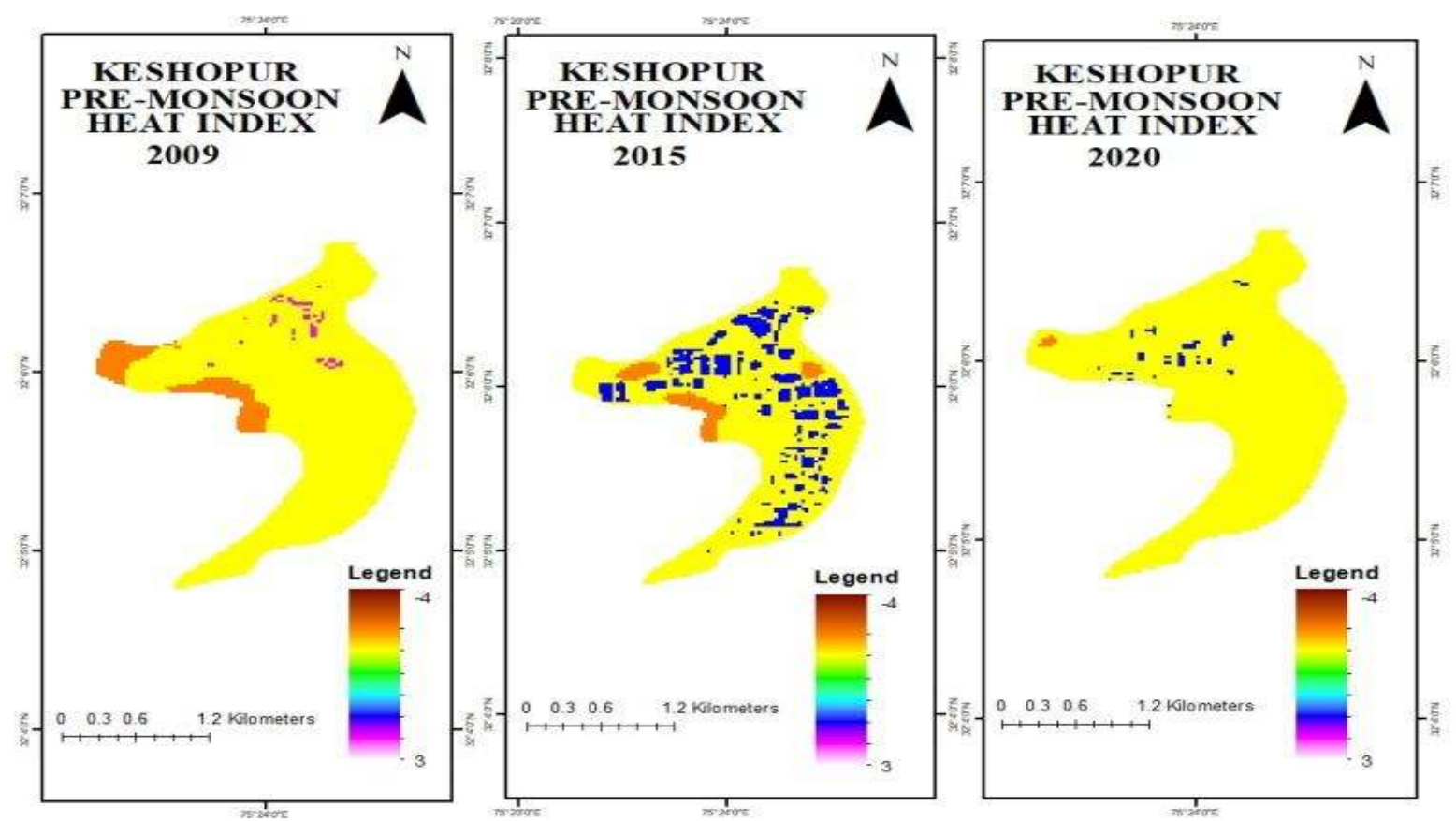




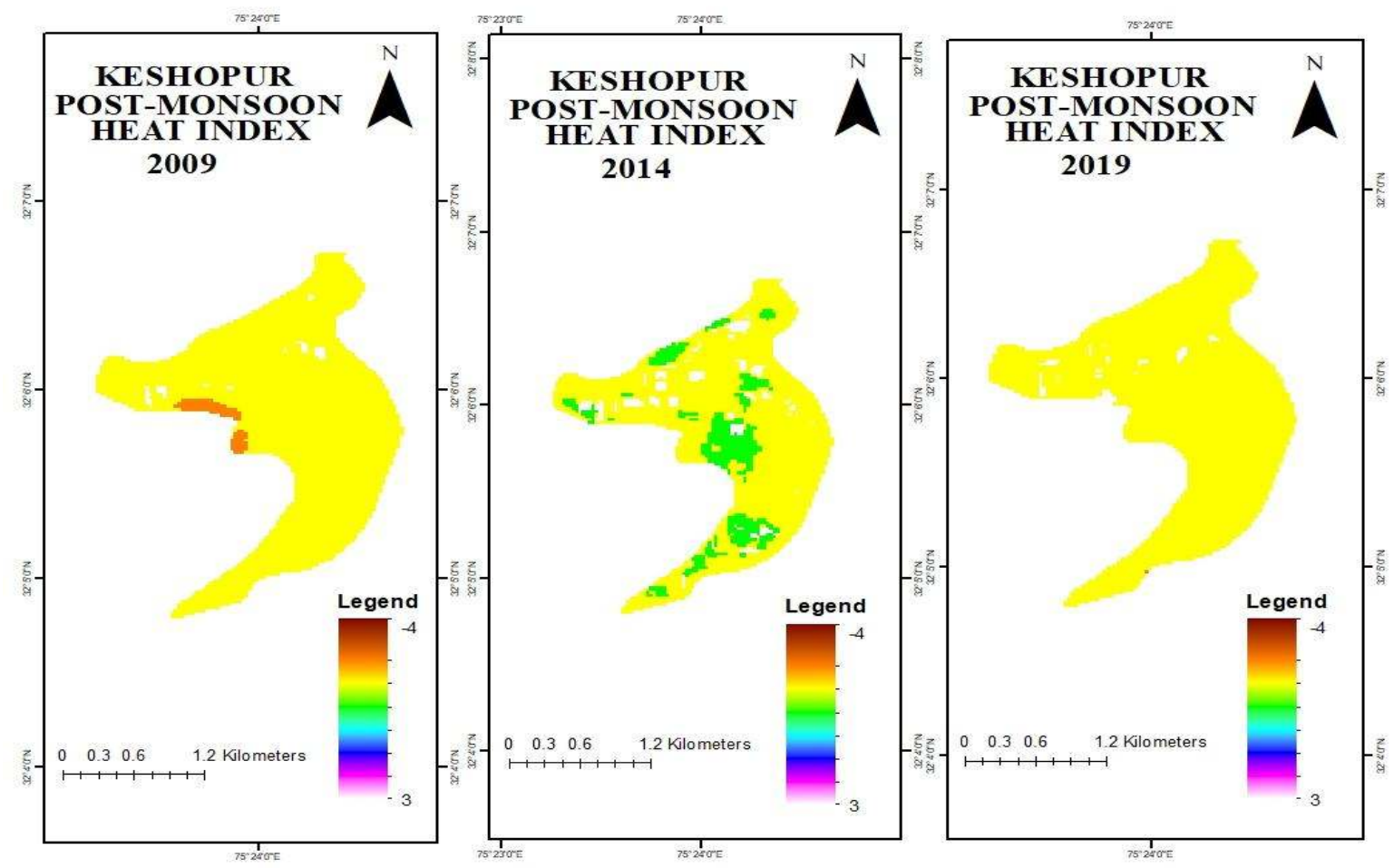

Figure 7:Variations of heat index derived from LST value over Keshopur wetlands during Pre- and PostMonsoon period.

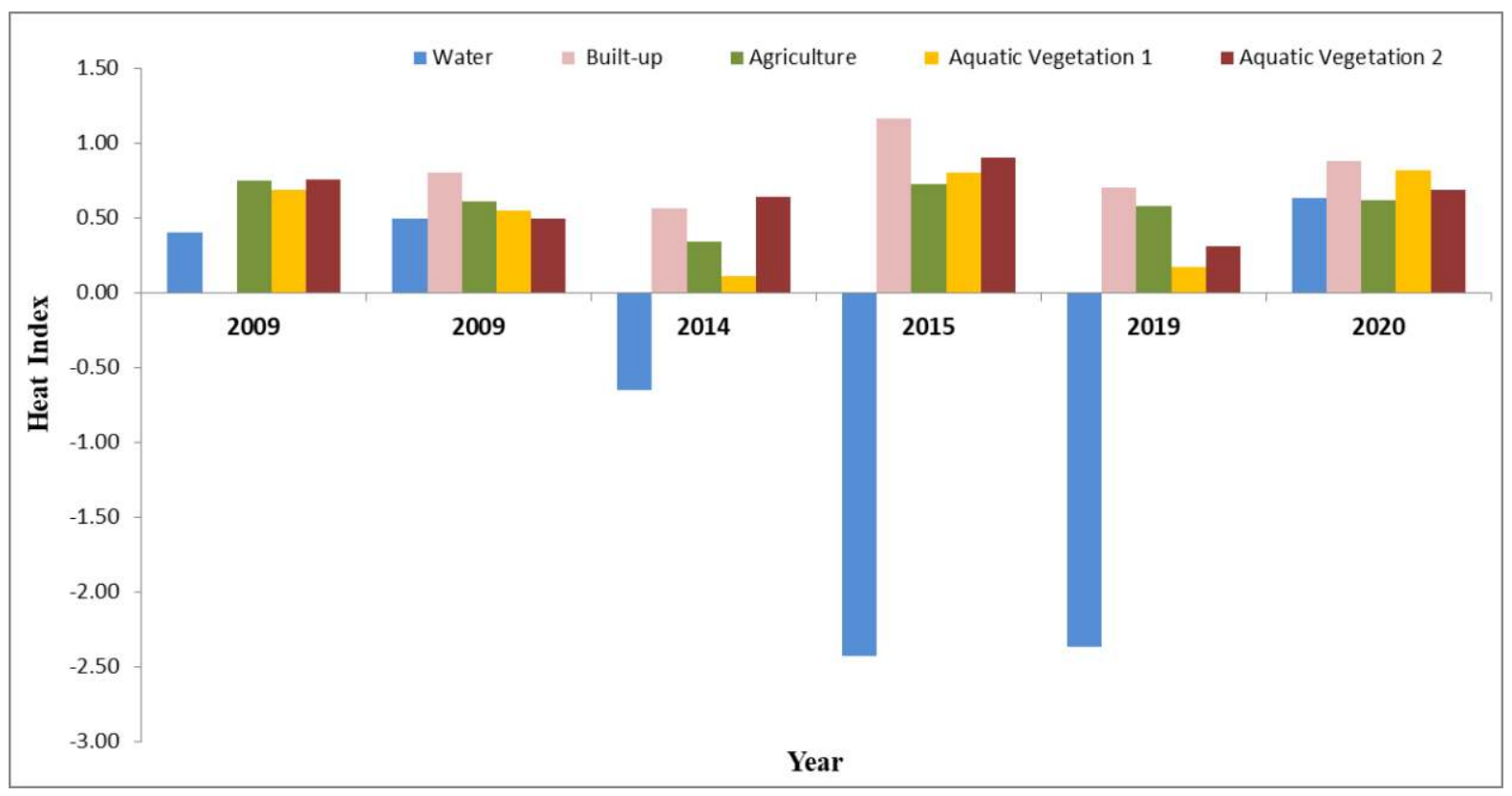

Figure 8: Shows the graphical representation of effect of heat index on each wetland class over Keshopur wetland. 
Over Harike wetland, the high effect of HI has been seen in built-up from 2009 to 2020 and the most changes have taken place in 2020 where the $\mathrm{HI}$ has been observed positive in all categories (Figure 6). It can be because of global changes, pollution or climatic effects and man-made activities. However, Keshopurwetland has not observed much change during period from 2009 to 2020. Only minor changes have been observed which have taken place in 2015. The maximum changes have been observed in the built-up class (Figure 8).

\section{CONCLUSION}

This study concludes that wetland changes over Punjab region is major concern due to pressure from long term climate changes and man-made activities.Landsat imagery has been used for mapping and monitoring of wetland ecosystems during pre and post monsoon season. A significant change has been observed over Harike and Keshopurwetlands. Many wetlands have been converted in agricultural and built-up. The intense anthropogenic activities have resulted more changes in the wetlands. Remote sensing study is particular useful for the monitoring of wetland ecosystems over Punjab.This study indicates that wetland monitoring is essential for sustainable management of ecosystem and to reduce high impacts in the future. It will aid policy makers to understand the status of wetland over the regions.

\section{ACKNOWLEDGEMENT}

The authors are thankful to USGS site for providing respective Landsat series data in the Public domain. The authors express thanks to scientists and researchers from Punjab Remote Sensing Centre, Ludhiana for their valuable suggestions and support during in house paper review.

\section{REFERENCES}

1. Barros, D.F. and Albernaz, A.L.M. (2014). Possible impacts of climate change on wetlands and its biota in the Brazilian Amazon. Brazilian Journal of Biology, 74 (4), 810-820.
2. Erwin, K.L. (2009). Wetlands and global climate change: the role of wetland restoration in a changing world. Wetlands Ecology and Management, 17 (1), 71-84. http://dx.doi.org/ 10.1007/ s11273-008-9119-1.

3. Ferrati, R., Canziani, G.A. and Moreno, D.R. (2005). Estero delibera: Hydrometeorological and hydrological characterization. Ecological Modelling, 186, 3-15.

4. Finlayson, C.M. and Davidson, N.C., summary report. In Finlayson, C.M, and Spiers, A.G. (eds). (1999). Global Review of Wetland Resources and Priorities for Wetland Inventory, Supervising Scientist Report 144, Canberra, 1-13.

5. Hulme, P.E. (2005). Adapting to climate change: is there scope for ecological management in the face of a global threat? Journal of Applied Ecology, 42, 784-794.6. IPCC (International Panel on Climate Change) (1996).Climate change 1996 - impacts, adaptations and mitigation of climate change: scientific technical analysis. Contribution of working group II to the second assessment report of the IPCC. Cambridge University Press, Cambridge.

7. IPCC,2007a: Climate Change 2007: Synthesis Report. Contribution of Working Groups I, II and III to the Fourth Assessment Report of the Intergovernmental Panel on Climate Change. Geneva.

8. Junk, W.J., An, S.Q., Finlayson, C.M., Gopal, B., Kvet, J., Mitchell, S.A., Mitsch, W.J. and Robarts, R.D. (2013). Current state of knowledge regarding the world's wetlands and their future under global climate change: a synthesis Aquatic Science. 75, 151-167.

9. Klemas, V. (2011). Remote sensing of wetlands: Case studies comparing practical techniques. Journal of Coastal Research, 27 (3), 418-427. 
10. Kumar, V. and Chopra, A.K. (2009). Impact of climate change on biodiversity of India with special reference to Himalayan regionAn overview. Journal of Applied and Natural Science, 1 (1), 117-122.

11. Locas, J. and Lloréns, P. (2008). Impacts of climate change on wetland ecosystems. Climate Change and Wetlands, pp. 1-14.

12. SAC. (2011). National wetland atlas. http://saconenvis.nic.in/publica tion\%5CNWIA_National_atlas.pdf.

13. Sahagian, D. and Melack, J. (1998). Global wetland distribution and functional characterization: trace gases and the hydrologic cycle. IGBP Report 46.

14. Sharma, C., Jindal, R., Singh, U.B. and Ahluwalia, A.S. (2018). Assessment of water quality of river Satluj, Punjab, India, Journal of Sustainable Water Resources Management, Volume 4, Issue 4, 809. doi: 10.1007/s40899017-0173-9.
15. Singh, S., Bhardwaj, A. and Verma, V.K. (2020). Remote sensing and GIS based analysis of temporal land use/land cover and water quality changes in Harike wetland ecosystem, Punjab, India. Journal of Environmental Management, 262 , doi.org/10.1016/j. jenvman.2020.110355.

16. Sivakumar, R. and Ghosh, S. (2016). Wetland spatial dynamics and mitigation study: an integrated remote sensing and GIS approach. Natural Hazards, 80, 975-995.

17. Kundpura, S., Kommoju, R. and Verma, I. (2019). Assessment of changes in wetland storage in Gurupura river basin of Karnatka, India, using Remote Sensing and GIS techniques. In: Rathinasamy, M., Chandramouli, S., Phanindra, K.B.V.N., Mahesh, U. (Eds.), Water Resources and Environment Engineering II. (C) Springer Nature Singapore, Pte Ltd., pp. 57-68. https://doi.org/10.1007/978-98. 